\title{
THE EFFECT OF SERVICES AND IMAGES ON TOURIST SATISFACTION AS USERS OF TRANS-JAKARTA TO TOURISM DESTINATIONS AT RAGUNAN WILDLIFE PARK DURING THE COVID-19 PANDEMIC
}

\author{
Gagih Pradini $^{1}$, Rahayu Lestri ${ }^{2}$, Resti Hardini ${ }^{3}$ \\ ${ }_{1,2,3}$ Universitas Nasional Jakarta \\ Email: gagih@civitas.unas.ac.id
}

\begin{abstract}
Tourism is one of the essential components to drive economic growth around the world in recent times, one of the tourism activities is visiting tourism destinations. This research activity is expected to provide the correct strategic input for Transjakarta companies during the pandemic. The variables used are Service Quality (X1) and Image (X2). Determining the location and channel used to provide services to customers involves thinking about how to deliver or deliver services to customers and where this will be done. Problem Solving Orientation states and Dependent Satisfaction (Y1) where service, product, and image benchmarks are maintained during the pandemic despite following health protocols.
\end{abstract}

Keywords: Transjakarta, Service Quality, Product Quality, Image, and Satisfaction.

\section{A. INTRODUCTION}

Tourism is a proud industry for every country, including Indonesia. Tourism as an industry has the role of displaying to the world's eyes masterpieces of culture, extraordinary natural beauty, art that has aesthetics, and history that attracts many people to do tourism activities (Skowron-Markowska \& Nowakowska, 2021).

Tourism is a travel activity for a person's temporary stay outside the environment, usually not consecutively in one year to spend leisure time, business trips, or other purposes. People who carry out tourism activities are tourists. The goal of tourists traveling is to have fun and gain experience. Tourism is engaged in services consisting of tourist attractions, amenities, accessibility, community institutions, and supporting facilities contained in a tourism destination (Kebete \& Wondirad, 2019). Tourism is an activity that indirectly involves social life, both the community as visitors and tourists and providers of tourism objects (tourism destinations) and recipients of tourists. A tourism destination is a significant place to visit en route with an actual or perceived regional boundary, a basic geographic unit for producing tourism statistics (Tambovceva et al., 2020). As a tourism destination, Indonesia must be observant to see the potential it has to attract many tourists to visit Indonesia.

Tourism has the potential to develop, as a highly based on local potential (nature, culture, and services) is still recorded to grow by $4.19 \%$, above the average GDP growth in 1998-2002, which was recorded at minus $0.27 \%$. It is also interesting that when this nation was hit by a crisis of trust and global image, the cumulative growth of national tourist arrivals was still quite convincing, amounting to an average of $9.40 \%$ in $1988-2002$ with a gain of $4.31 \%$ of foreign tourists and domestic tourists by $10.20 \%$. Tourism as a foreign exchange contributor is reflected in 2000. Indonesia received $\mathrm{Rp} 55.16$ trillion from 5.06 million foreign tourists who visited. In 2008, the state revenue increased to Rp 80.46 trillion, in line with the increase in 
visits to 6.42 million people (Supriyadi, 2018). The years 2020 and 2021 have been tough years for the tourism industry due to the COVID-19 pandemic, which has resulted in a decrease in the number of visits to existing tourism destinations, with this research it is hoped that this research will provide a concrete picture and produce the right strategy (Lim \& To, 2021).

Excellent and correct management of tourism destinations is needed to feel at home and stay longer in tourism destinations that they think are comfortable for them to remain in the tourism destinations they visit. The longer tourists stay in a tourism destination, the more money will circulate in the tourism destination and increase the income of the local community (Su et al., 2019).

One of the sectors in tourism activities affected by COVID-19 is the transportation sector. The transportation sector is everything that includes forms and types of public transportation, especially those operating along transit lines connecting places of origin and destinations of tourists. For example, airlines, buses, car rentals, trains, and so on (Zhang et al, 2019). It is unavoidable that the forms of public transportation that transport tourists to visit tourist destinations are very diverse, in the form of privately rented public transportation such as taxis, motorcycle taxis, bajaj, rental cars, and mass transportation buses, trains, and airplanes. In the early hours of the morning, mass transportation is needed by the wider community to travel, one of which is Transjakarta which brings tourists to tourism destinations in DKI Jakarta (Ellisa \& Luana, 2021).

Transjakarta, as one of the tourism sectors that have users with the motive of traveling on weekends or holidays, also needs to be considered by the manager to increase tourist satisfaction. Considering the Transjakarta train as one of the choices for tourists to carry out tourism mobility (Metze \& Tovaas, n.d.). As an industry, the products produced and quality services and superior value are crucial things to maximize customer satisfaction and loyalty. In addition, the company's image is a means that can distinguish one manager from another (Ozkan et al., 2019). Thus, it is imperative to know tourists' satisfaction and how much tourists want to reuse this mode of transportation on holidays or weekends for sightseeing.

Therefore, it is pretty interesting for researchers to examine the effect of service and image on tourist satisfaction as Transjakarta users to tourism destinations at the Ragunan Wildlife Park during the Covid-19 pandemic.

\section{B. LITERATURE REVIEW}

\section{Service}

According to Aaker, the definition of acceptable quality is the customer's perception of the overall quality or superiority of a product or the excellence of a product or service for the intended purpose (Stylidis et al., 2020). According to Parasuraman, the assessment of service quality is a global consideration or attitude related to the superiority of service or global care or consumer considerations about the overall worth of a company (Schill \& Winkel, 2021).

According to Zeithaml in Parasuraman, suggests five dimensions in determining service quality, namely: Reality, responsiveness, assurance, empathy, and tangible:

a. Reliability, namely the ability to provide the promised service performance quickly and accurately.

b. Responsiveness, namely the willingness of the staff to help customers and provide responsive service. 
c. Assurance; which includes the knowledge, courtesy, and ability of the team to create trust and certainty of benefit.

d. Empathy; is a condition for caring and giving personal attention.

e. Tangibles (Physical Evidence); which include physical facilities, equipment, employees, and means of communication.

\section{Product Quality}

According to Sofjan Assauri, products purchased by consumers can be divided into three levels (Pitari et al., 2020), namely:

a. The core product is the real core or basis of the product that a buyer or consumer wants to get from the product.

b. Formal products are the form, quality, and packaging that accompany the product.

c. Additional products are additional legal products with various accompanying services. Garvin describes the dimensions for product quality in the form of tangible goods. Garvin states that there are eight dimensions to determine product quality (Hoe \& Mansori, 2018), namely:

a. Performance; this dimension is about how well a product does what it has to do and leads to the core product character, which includes the brand, measurable attributes, and aspects of its performance and operating characteristics.

b. Features; This dimension can be in the form of additional details that complement or enhance the function of the core product and because it acts as a compliment, it is flexible to changes.

c. Reliability; This dimension relates to the product's ability to withstand regular use or from the possibility of malfunctioning for a certain period. If the product is considered unreliable, then when it is damaged, it requires a large amount of repair and maintenance costs.

d. Conformance; this dimension relates to how well the product conforms to industry standards.

e. Durability; This dimension as a measure of the durability of a product includes economic or technical aspects. Judging from the size, age of the product, and modern technology that makes it possible.

f. Serviceability; This dimension relates to products used for a long time and often need to be repaired or maintained. Product designs that will facilitate repairs add value to the product if problem-solving can be resolved quickly.

g. Aesthetics; This dimension relates to how the product is seen, felt, and heard.

h. Perceived Quality; This dimension includes the category of brand reputation, including the influence of brand image and other intangible factors that can affect consumer perceptions of quality.

\section{Company Image}

According to Abdi, the image is a reflection or reproduction of the identity of individuals, objects, or organizations. Image is an impression of the object field stored in memory (Anderson \& Lin, 2019). For companies, image is also defined as the public's perception of the company. People's perceptions are based on what they know or think about 
the company. People's perception of the company on what they know or think about the company (Astrachan \& Botero, 2018).

\section{Satisfaction}

According to Kotler, satisfaction is a form of feeling happy or disappointed by someone, which results from a comparison between the performance of the product received and what is expected (Wantara \& Tambrin, 2019).

According to Javalgi in Jones, he believes that the company's foundation to survive is loyal customers. For this reason, companies are required to cultivate their respective competitive advantages through creative, innovative, and efficient efforts so that they become the choice of many customers who, in turn, are expected to be loyal (Radzi et al., 2017).

\section{METHOD}

The research was conducted using descriptive and inferential analysis methods. The data used are primary data obtained directly. The number of samples used was as many as 100 people. The object of research in this study is the mix of Service Quality (X1), Image (X2), and Satisfaction (Y1) as endogenous variables. Then the instrument test was carried out in the form of validity and reliability tests. Data analysis is assisted by the SPSS program to speed up analysis results.

\section{RESULT AND DISCUSSION}

\section{Characteristics of Respondents}

a. Respondent Profile

The following is a profile of respondents from 100 questionnaires used in this study. The return rate for the questionnaire in this study was $100 \%$. The distribution method used by researchers is by distributing questionnaires. In this study, the characteristics of the respondents in question are gender and age.

Table 1. Profile of Respondents by Gender

\begin{tabular}{|rl|r|r|r|r|}
\hline & & Frequency & Percent & Valid Percent & Cumulative Percent \\
\hline Valid & & 1 & 1.0 & 1.0 & 1.0 \\
& Man & 38 & 38.0 & 38.0 & 39.0 \\
& Woman & 61 & 61.0 & 61.0 & 100.0 \\
\hline & Total & 100 & 100.0 & 100.0 & \\
\hline
\end{tabular}

Based on table 1, the research results through the distribution of this questionnaire indicate that the number of respondents of the male sex is $38 \%$ or as many as 38 respondents. As for the female gender is $61 \%$ or as many as 61 respondents. In this case, it can be seen that female passengers dominate TransJakarta users.

Table 2. Profile of Respondents by Age

\begin{tabular}{|rl|r|r|r|r|}
\hline & & Frequency & Percent & Valid Percent & Cumulative Percent \\
\hline Valid & $18-25$ & 86 & 86.0 & 86.0 & 86.0 \\
& $26-35$ & 14 & 14.0 & 14.0 & 100.0 \\
& Total & 100 & 100.0 & 100.0 & \\
\hline
\end{tabular}


Based on table 2 regarding the characteristics in the age category, it is known that the number and percentage of respondents aged 18-25 years are 86 people or $86 \%$, respondents aged 26-35 years are 14 people or $14 \%$.

b. Descriptive Analysis

Based on the calculation of the questionnaire results, this result explains that the average total means known that the independent variable of service quality has the highest average total mean value of 4.25 with the highest mean of 4.46 , namely Transjakarta has more reliability than other products.

The independent variable brand image has the lowest total mean value of 3.93 with the lowest mean of 3.86, namely Transjakarta, which is well known to many people. While the dependent variable, consumer satisfaction, has an average total mean value of 3.99 with the lowest mean of 3.79 , consumers have pleasure using Transjakarta compared to other modes of transportation.

The quality of the TransJakarta service brand image needs to be improved to influence and increase customer satisfaction.

\section{Research Estimation Results}

a. Validity test

The results of the validity test were carried out on questionnaires distributed to 100 respondents who used Transjakarta. Based on the research validity test results, it can be seen that all items are declared valid. The criterion is the Corrected item-total correlation (r-count) value which is greater than the $r$ table value, with the following criteria:

a. If the value of $r$ count $>r$ table, then the instrument is valid

$b$. If the value of $r$ count $<r$ table, then the instrument is not valid

The value of $r$ table is obtained by calculating the degrees of freedom from the data, which is 100 (n). Furthermore, based on the results of data processing using SPSS version 23 software, it is known that all $r$ count are calculated at a significance level of 0.05 . The value of $r$ table for $n=100$ with a significance level of 0.05 is 0.196 .

b. Reliability Test

In this study, Cronbach's Alpha ( $\alpha$ ) statistical test was carried out to measure reliability. A questionnaire item is said to be reliable if it gives Cronbach's Alpha value 0.60.

Furthermore, the table of data processing results to test the reliability of the data with the SPSS program on the instruments of product quality, brand image, advertising, and consumer satisfaction is as follows:

Table 3. Reliability Statistics

\begin{tabular}{|r|r|}
\hline Cronbach's Alpha & N of Items \\
\hline .951 & 24 \\
\hline
\end{tabular}

Based on the results of the reliability test that has been carried out, the Cronbach's Alpha $(\alpha)$ score is 0.951 . Then it is declared reliable because the value of Cronbach's Alpha $(\alpha)$ exceeds 0.60 . The results of data processing in table 4.13 can be seen that all variable items are reliable. 


\section{Classic assumption test}

a. Normality test

The next test is the normality test used to determine whether the data population is normally distributed or not (Mishra et al, 2019). The normal distribution will form a straight diagonal line, and plotting data will be compared with the diagonal line. If the data distribution is normal, the line that gives the actual data will follow the diagonal line.

From the study results, normal probability plots show that existing data are spread out close to the diagonal. Then the regression model has met the requirements of the normality assumption.

b. Multicollinearity Test

Multicollinearity test is seen from the value of Variance Inflation Factor (VIF). The multicollinearity problem is shown if the VIF number is more than 10 (ten) (Salmeron et al, 2018). In this study, researchers have simultaneously conducted a multicollinearity test on three independent variables (brand awareness, perceived quality, and advertising).

The research results show that the Variance Inflation Factor (VIF) value of the service quality variable is 1.790 , the brand image variable is 1.790 . Of the two variables, the VIF value is smaller than ten, so it can be said that between the independent variables, there is no multicollinearity problem.

c. Autocorrelation Test

Autocorrelation test is performed to see whether there is autocorrelation in a regression model using the Durbin-Watson test as follows:

Table 4. Correlation Test

\begin{tabular}{|l|c|r|r|r|r|}
\hline Model & R & R Square & Adjusted R Square & Std. Error of the Estimate & Durbin-Watson \\
\hline 1 & .862 & .747 & .742 & .29474 & 2.233 \\
\hline
\end{tabular}

Autocorrelation is a correlation between the residuals in period t with residuals in the previous period (t-1). The autocorrelation test method was carried out using the DurbinWatson (DW) test. Based on table 4, it can be seen that the DW value is 2.009.

Decision-making basis:

1) $\mathrm{DU}<\mathrm{DW}<4$-DU then it is accepted, which means there is no autocorrelation

2) DW $<$ DL or DW $>4$-DL then it is rejected, which means there is an autocorrelation

3) $\mathrm{DL}<\mathrm{DW}<\mathrm{DU}$ or 4-DU $<\mathrm{DW}<4$-DL means there is no definite conclusion

DU and DL values can be obtained with the Durbin Watson statistical table. With $\mathrm{n}=$ 103 , and $\mathrm{k}=2$, the value of $\mathrm{DL}=1.6337$, and $\mathrm{DU}=1.7152$, so that the value of $4-\mathrm{DU}$ $=2.32$, and 4-DL 2.3663 .

It can be seen that the Durbin-Watson value of 2.009 lies between DU $<$ DW $<4$-DU so that the results do not occur autocorrelation. Thus, there is no correlation between the independent variables in the linear regression model, and there is no autocorrelation disorder, either positive or negative, in the regression model.

d. Heteroscedasticity Test

From the output results, it can be seen that the significant value of each independent variable, both product quality, brand image, and advertising is greater than $\alpha=0.05$ it 
means that there is no independent variable that affects the dependent variable, so it can be concluded that the regression model does not contain heteroscedasticity and the research can be continued.

\section{Hypothesis testing}

a. F Test

The initial stage of this research is to estimate whether or not the regression model is feasible to explain the effect of the independent variable on the dependent variable. This study conducted a model reliability test or model feasibility test or more popularly referred to as the F Test. This test is called the F test because it follows the F distribution whose test criteria are like One Way Anova. Hypothesis testing between Product Quality, Image on consumer satisfaction can be used by looking for F test statistics by comparing F-count with F-table.

Ho: It is suspected that Product Quality (X1) and Brand Image (X2) have no real and significant effect on consumer satisfaction.

Ha: It is suspected that Product Quality (X1), Brand Image (X2) together have a real and significant effect on consumer satisfaction.

With test criteria by comparing F-count with F-table

Ho: Rejected, if F-count > F-table $(\alpha 0.05)$

Ha: Accepted if F-count $<$ F-table $(\alpha 0.05)$

The significance of this test is used to determine whether the independent variables developed in this study can explain the variation of changes in the dependent variable.

Table 5. F Test

\begin{tabular}{|c|c|c|c|c|c|}
\hline Model & Sum of Squares & df & Mean Square & $\mathrm{F}$ & Sig. \\
\hline 1 Regression & 24.876 & 2 & 12.438 & 143.181 & .000 \\
\hline Residual & 8.426 & 97 & .087 & & \\
\hline Total & 33.303 & 99 & & & \\
\hline
\end{tabular}

From table 5 above it can be explained that the F-count value is 143.181 with a significant level of 0.000 , after the F-value is calculated, the F-table value $(\alpha 0.05)$ and df $1=2$ : df $2=100-2-1=97$ is 3.09. Because the F-count is greater than the F-table $(143.181>3.09)$, it can be concluded that Ho is rejected, meaning Product Quality, Brand Imaged together to have a significant effect on Consumer Satisfaction of TransJakarta users.

b. Coefficient of Determination Test $\left(\mathrm{R}^{2}\right)$

The $\mathrm{F}$ test in the previous calculation has proven that there is an influence between the independent variables on the dependent variable. In the next stage, researchers want to know how big the proportion of the influence of all independent variables on the dependent variable is called the Coefficient of Determination which can be measured by the value of $R$ square $\left(R^{2}\right)$.

Based on the calculation results, the $\mathrm{R} 2$ value is 0.747 or $74.7 \%$. This means that the independent variables in this study (Product Quality, Brand Image, and Advertising) have a proportion of influence on the dependent variable (consumer satisfaction) of 
$74.7 \%$. At the same time, the remaining $25.3 \%$ is influenced by other variables that are not in the linear regression model.

c. T Test

The $\mathrm{T}$ test in multiple linear regression is intended to test whether the parameters (regression coefficients and constants) that are expected to estimate the equation or multiple linear regression model are the correct parameters or not. The exact meaning here is that the parameter can explain the behavior of the independent variable in influencing the dependent variable. Parameters estimated in linear regression include constants and coefficients in linear equations. In this section, the t-test is focused on the regression coefficient only. So, the t-test in question is the regression coefficient test. Hypothesis testing between Product Quality, Brand Image, and Advertising on Consumer Satisfaction can be used by looking for t-test statistics with the criteria for comparing the $\mathrm{t}$-count and $\mathrm{t}$-table values as follows:

Ho: Rejected, if $\mathrm{t}$-count $>\mathrm{t}$-table with $0.05 / 3(\mathrm{dk}=\mathrm{n}-\mathrm{k}-1)$

Ha: Accepted, if t-count < t-table with $0.05 / 3(\mathrm{dk}=\mathrm{n}-\mathrm{k}-1)$

The t-test using coefficients analysis with SPSS 23 processing obtained the following data:

Table 6. T test

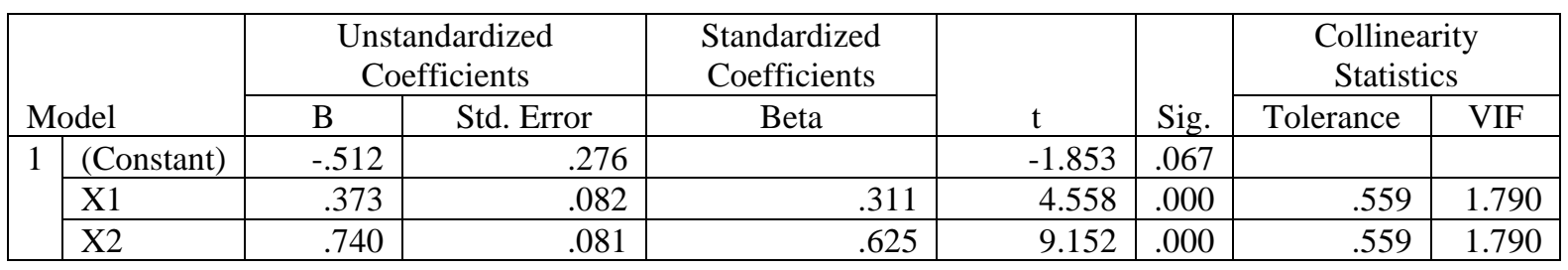

\section{Product Quality Variable Coefficient Test}

From table 6 above, it can be explained that the quality of service has a t-count value of 4.558 and a significant 0.000 . While the product quality of the $\mathrm{t}$-table value at $\mathrm{dk}=\mathrm{n}-\mathrm{k}-1$ (100-2-1) ( $\alpha$ 0.025 two-tailed) so that the obtained t-table is 1.984. Because t-count $>\mathrm{t}$-table $(4.2558>1.984)$, it can be concluded that Ho is rejected, which means that service quality $(\mathrm{X} 1)$ has a positive and significant effect on consumer satisfaction (Y) Transjakarta.

\section{Brand Image Variable Coefficient Test}

From table 6 above, it can be explained that the t-count value of a brand image is 9.152 and significance is 0.000 . While the brand image of the t-table value at $\mathrm{dk}=\mathrm{n}-\mathrm{k}-1(100-2-1)(\alpha$ 0.025 two-tailed) to obtain a t-table of 1.984 . Because t-count $>$ t-table $(9,152>1,984)$, then Ho is rejected, which means that brand image (X2) has a positive and significant effect on consumer satisfaction (Y) Transjakarta.

\section{E. CONCLUSION}

TransJakarta as a mode of public transportation in Jakarta, continues to improve its class into modern and integrated transportation. With the existing network, TransJakarta continues to expand its network to help residents of the capital carry out their daily activities, including traveling in Jakarta. The quality of TransJakarta services continues to be improved to win the hearts of the capital city's citizens to switch from private transportation to public 
transportation. The excellent service provided by TransJakarta brought the peak of this user achievement in 2016. Now TransJakarta has become an inseparable part of the capital. Then the quality of service has a positive and significant effect on tourist satisfaction. This can be interpreted if the quality of service can be continuously improved, then tourist satisfaction will increase even more. Then the image of TransJakarta has a positive and significant effect on tourist satisfaction. This can be interpreted if the image can continue to be improved, then tourist satisfaction will increase even more.

\section{REFERENCES}

Anderson, A. J., \& Lin, F. (2019). How pattern information analyses of semantic brain activity elicited in language comprehension could contribute to the early identification of Alzheimer's disease. NeuroImage: Clinical, 22, 101788.

Astrachan, C. B., \& Botero, I. C. (2018). "We are a family firm": An exploration of the motives for communicating the family business brand. Journal of Family Business Management.

Ellisa, E., \& Luana, L. (2021). Female restrooms in the tourist destination: how the sociospatial conditions of public toilets influence women's perception of safety. Journal of Asian Architecture and Building Engineering.

Hoe, L. C., \& Mansori, S. (2018). The effects of product quality on customer satisfaction and loyalty: Evidence from Malaysian engineering industry. International Journal of Industrial Marketing, 3(1), 20.

Kebete, Y., \& Wondirad, A. (2019). Visitor management and sustainable destination management nexus in Zegie Peninsula, Northern Ethiopia. Journal of Destination Marketing \& Management, 13, 83-98.

Lim, W. M., \& To, W. M. (2021). The economic impact of a global pandemic on the tourism economy: the case of COVID-19 and Macao's destination-and gambling-dependent economy. Current Issues in Tourism, 1-12.

Metze, A., \& Tovaas, K. (Eds.). Compilation of 50 case study profiles; overviews and in-depth investigations. Transportation Planning and Technology, 36(1), 76-92.

Mishra, P., Pandey, C. M., Singh, U., Gupta, A., Sahu, C., \& Keshri, A. (2019). Descriptive statistics and normality tests for statistical data. Annals of cardiac anaesthesia, 22(1), 67.

Özkan, P., Süer, S., Keser, İ. K., \& Kocakoç, İ. D. (2019). The effect of service quality and customer satisfaction on customer loyalty: The mediation of perceived value of services, corporate image, and corporate reputation. International Journal of Bank Marketing.

Pitari, D. F., Gayatri, G., Furinto, A., \& Assauri, S. (2020). Integration of intention and resistance in adopting near field communication-based mobile payment innovation. International Journal of Scientific and Technology Research, 9(4), 857866.

Radzi, K. M., Nor, M. N. M., \& Ali, S. M. (2017). The impact of internal factors on small business success: A case of small enterprises under the FELDA scheme. Asian Academy of Management Journal, 22(1), 27.

Salmerón, R., García, C. B., \& García, J. (2018). Variance inflation factor and condition number in multiple linear regression. Journal of Statistical Computation and Simulation, 88(12), 2365-2384.

Schill, M., \& Godefroit-Winkel, D. (2021). Consumer responses to environmental corporate social responsibility and luxury. Journal of Services Marketing. 
Skowron-Markowska, S., \& Nowakowska, M. (2021). Chinese Destinations Related to Martial Arts Tourism from the UNESCO Perspective. Sustainability, 13(14), 7581.

Stylidis, K., Wickman, C., \& Söderberg, R. (2020). Perceived quality of products: a framework and attributes ranking method. Journal of Engineering Design, 31(1), 37-67.

Su, M. M., Wall, G., Wang, Y., \& Jin, M. (2019). Livelihood sustainability in a rural tourism destination-Hetu Town, Anhui Province, China. Tourism Management, 71, 272-281.

Supriyadi, E. (2018). Analysis of Tourism Destination Loyalty of Ragunan Zoo in Jakarta. Journal of Environmental Management and Tourism (JEMT), 9(02 (26)), 276282.

Tambovceva, T., Atstaja, D., Tereshina, M., Uvarova, I., \& Livina, A. (2020). Sustainability challenges and drivers of cross-border greenway tourism in rural areas. Sustainability, 12(15), 5927.

Wantara, P., \& Tambrin, M. (2019). The effect of price and product quality towards customer satisfaction and customer loyalty on madura batik. International Tourism and Hospitality Journal, 2(1), 1-9.

Zhang, A., Wan, Y., \& Yang, H. (2019). Impacts of high-speed rail on airlines, airports and regional economies: A survey of recent research. Transport Policy, 81, A1-A19. 